\section{Gategory}

Metal-Mediated

Synthesis

\section{Key words}

copper

indium

S. THAPA, S. K. GURUNG, D. A. DICKIE, R. GIRI* (UNIVERSITY OF NEW MEXICO, ALBUQUERQUE, USA)

Copper-Catalyzed Coupling of Triaryl- and Trialkylindium Reagents with Aryl Iodides and Bromides through Consecutive Transmetalations

Angew. Chem. Int. Ed. 2014, 53, 11620-11624.

\title{
Copper-Catalyzed Coupling of Indium Reagents
}

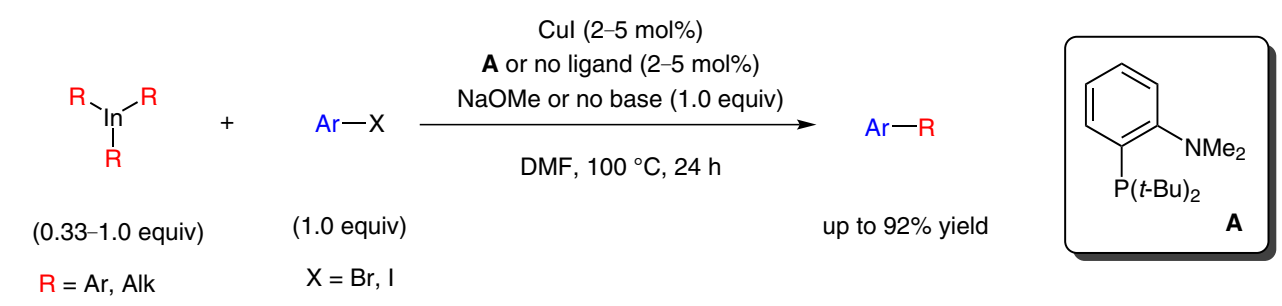

Selected examples:<smiles>COc1cccc(-c2ccnc3cc(Cl)ccc23)c1</smiles>

$80 \%$ yield<smiles>CCC(C)c1ccnc2cc(Cl)ccc12</smiles>

$81 \%$ yield<smiles>c1ccc(-c2cnccn2)cc1</smiles>

$85 \%$ yield<smiles>CC(C)CCc1ccnc2cc(Cl)ccc12</smiles>

$87 \%$ yield<smiles>COc1ccccc1-c1cc(C(F)(F)F)cc(C(F)(F)F)c1</smiles>

$74 \%$ yield<smiles>CC(C)c1ccnc(Cl)c1</smiles>

$54 \%$ yield
Significance: Giri and co-workers describe a copper(I)-catalyzed coupling of triorganoindium reagents with aryl iodides and bromides. This reaction shows high functional group tolerance, while being compatible with sterically hindered substrates, leading to the expected products in good yield.
Comment: The reaction can be performed with low catalyst loadings (2 mol\%) and only requires 0.33 equivalents of the triorganoindium reagent with respect to the aryl halide. 